\title{
Wysoki Przedstawiciel Unii Europejskiej do Spraw Zagranicznych i Polityki Bezpieczeństwa jako przedsiębiorca polityczny. Propozycja podejścia badawczego ${ }^{1}$
}

\section{Wprowadzenie}

W 2019 r. minęło dziesięć lat od wejścia w życie traktatu z Lizbony, który przyniósł znaczącą instytucjonalizację i dalsze „uwspólnotowienie” (Miszczak, 2008, s. 247) polityki zagranicznej i bezpieczeństwa poprzez powołanie do życia dwóch aktorów: Wysokiego Przedstawiciela Unii Europejskiej do Spraw Zagranicznych i Polityki Bezpieczeństwa (dalej: Wysoki Przedstawiciel) łączącego funkcję przewodniczącego Rady do Spraw Zagranicznych i wiceprzewodniczącego Komisji Europejskiej² oraz unijnej służby dyplomatycznej - Europejskiej Służby Działań Zewnętrznych (ESDZ). Zmiany te dokonały się pomimo ochrony przez państwa członkowskie swoich kompetencji decyzyjnych i ich ,zwyczajowej roli dominującej” (Moravcsik, 1999, s. 285) wynikającej z niechęci do ,rozszerzenia integracji na sfery tradycyjnie zaliczane do atrybutów suwerenności” (Zięba, 2018, s. 229). Tuż po wejściu w życie traktatu, polityka zagraniczna znalazła się jednakże poza sferą zainteresowań państw członkowskich ze względu na wybuch kryzysu finansowego (Żurawski vel Grajewski, 2012, s. 21-22) i konieczności koncentracji wysiłków na ratowaniu strefy euro. Z tego względu nowopowstali aktorzy - Wysoki Przedstawiciel i ESDZ - konstytuowali się początkowo w cieniu kryzysu i bez większego zaangażowania państw członkowskich (Helwig, Rüger, 2014, s. 1). Jednakże, wydarzenia w południowym i wschodnim sąsiedztwie Unii Europejskiej - Arabska Wiosna, wojna w Libii i Syrii, Euromajdan, rosyjska agresja na Ukrainę - sprawiły, że kwestie bezpieczeństwa powróciły na agendę polityczną pod koniec 2013 r. Od tego czasu, w konkluzjach każdego szczytu Rady Europejskiej, tematy związane z polityką zagraniczną, bezpieczeństwa i obronnością są obecne (European Council, 2013, 2015a, 2015b, 2017, 2018). Powtarzającym się przesłaniem była konieczność zwiększenia aktywności Unii na arenie międzynarodowej w obliczu zagrożeń zewnętrznych i lepszej koordynacji i spójności jej działań. Kluczowym stanowiskiem mającym w myśl traktatu z Lizbony poprawić spójność między poszczególnymi elementami działań zewnętrznych jest właśnie Wysoki Przedstawiciel wspomagany w swoich działaniach przez ESDZ. Catherine Ashton, która

${ }^{1}$ Publikacja powstała $\mathrm{w}$ ramach projektu finansowanego przez Narodowe Centrum Nauki na mocy decyzji UMO-2018/31/B/HS5/03694.

${ }^{2}$ O wcześniejszym stanowisku Wysokiego Przedstawiciela, pełnionym w latach 1999-2009 przez Javiera Solanę, zob.: Zięba, 2003, 2007. 
jako pierwsza pełniła to stanowisko, równolegle do koordynowania unijnej polityki zagranicznej w obliczu narastających zagrożeń, musiała zbudować unijną dyplomację oraz wypracować mechanizmy współdziałania między ESDZ a Komisją Europejską i Parlamentem Europejskim. Konieczność koncentracji na kwestiach instytucjonalnych, położyła się cieniem na jej aktywności operacyjnej i była jednym z powodów nasilającej się krytyki w mediach wobec jej osoby (por. Przybylska-Maszner, 2012, s. 45-46). Federica Mogherini, która jako druga objęła stanowisko Wysokiego Przedstawiciela, zastała ESDZ w pełni zdolną do działania i mogła skoncentrować się na aktywności operacyjnej realizując mandat powierzony jej na mocy zapisów traktatowych. Wydarzenia na arenie międzynarodowej, jak wzrost znaczenia państwa islamskiego i eskalacja wojny w Syrii, aneksja Krymu przez Rosję i kryzys migracyjny, wystawiły na próbę przebudowaną traktatem z Lizbony architekturę unijnej polityki zagranicznej.

Niniejszy artykuł analizuje postlizbońską dynamikę instytucjonalną w zakresie unijnej polityki zagranicznej i bezpieczeństwa. Wykorzystując koncepcję politycznego przedsiębiorcy (policy entreprenuer) (Kingdon, 2003), opracowanie koncentruje się na roli Wysokiego Przedstawiciela, gdyż od tego stanowiska oczekiwano poprawy efektywności unijnej polityki zagranicznej i przez to zwiększenia roli UE jako aktora międzynarodowego ${ }^{3}$. Celem pracy jest zaproponowanie podejścia badawczego opartego na koncepcji politycznego przedsiębiorcy, które pozwoli na analizę roli, jaką Wysoki Przedstawiciel odgrywa w procesie decyzyjnym. Zaproponowany tutaj model jest komplementarny wobec powszechnie stosowanych koncepcji badawczych w badaniach procesu decyzyjnego w zakresie unijnej polityki zagranicznej.

Artykuł składa się z trzech części. W pierwszej części pokazana jest specyfika mandatu Wysokiego Przedstawiciela i stan badań dotyczący roli tego stanowiska w procesie decyzyjnym w zakresie polityki zagranicznej i bezpieczeństwa. W drugiej części zaproponowany jest model politycznego przedsiębiorcy i dokonana jego operacjonalizacja w odniesieniu do stanowiska Wysokiego Przedstawiciela - autorka definiuje zmienne zależne i niezależne oraz proponuje hipotezy badawcze, jakie model miałby zweryfikować. Trzecią część stanowią wnioski, w których autorka podsumuje wartość eksploracyjną, jaką wnosi proponowany model i zaproponuje studia przypadku, które pomogłyby zweryfikować zawarte w nim hipotezy.

Artykuł korzysta z dorobku polskiej i zagranicznej literatury z zakresu integracji europejskiej oraz polityk publicznych. Przy formułowaniu hipotez przydatne okazały się także wywiady pogłębione z osobami z otoczenia osób pełniących funkcje Wysokiego Przedstawiciela, zarówno Catherine Ashton, która piastowała to stanowisko od 1 grudnia 2009 r. do 1 listopada 2014 r., jak i Federici Mogherini, pełniącej urząd od 1 listopada 2014 do 1 grudnia 2019 r. Wśród rozmówców byli m.in. Robert Cooper (doradca Catherine Ashton do spraw tworzenia ESDZ 2010-2011 oraz do spraw Birmy 2013-2014), Nathalie Tocci (specjalny doradca Mogherini do spraw Strategii

${ }^{3}$ Świadomie pominięta jest rola innych przedsiębiorców politycznych zaangażowanych w proces decyzyjny w tym obszarze takich jak Rada Europejska, Rada do Spraw Zagranicznych, Komisja Europejska i Parlament Europejski, gdyż tak kompleksowe rozważania wymagałyby obszerniejszej analizy. Temat tzw. konkurencyjnych przedsiębiorców (competitive entreprenuers) będzie poddany badaniom w ramach grantu przyznanego przez NCN na mocy decyzji UMO-2018/31/B/HS5/03694. 
Globalnej UE), Alfredo Conte (dyrektor Departamentu Planowania Strategicznego w ESDZ od 2011 do 2017 r.) i Maciej Popowski (zastępca Sekretarza Generalnego ESDZ 2011-2015, od 2016 r. zastępca Dyrektora Generalnego w Dyrekcji Generalnej „Europejska Polityka Sąsiedztwa). Autorka odbyła także rozmowy z przedstawicielami ministerstw spraw zagranicznych państw członkowskich (Polski, Niemiec, Estonii, Włoch, Belgii i Holandii), którzy życzyli sobie pozostać anonimowi.

\section{Mandat Wysokiego Przedstawiciela}

Traktat z Lizbony i wprowadzone przez niego zmiany w zakresie polityki zagranicznej i bezpieczeństwa zostały wielokrotnie opisane w literaturze przedmiotu i nie ma potrzeby ponownej analizy jego zapisów (Miszczak, 2008; Węc, 2011, 2015; Grzeszczak, 2013; Rewizorski, Przybylska-Maszner, 2013; Starzyk-Sulejewska, 2013; Tereszkiewicz, 2013; Sus 2014; Chrusciel, 2015; Zięba, 2018; Eysymontt 2019). Na użytek niniejszego opracowania wystarczy przypomnieć, że nowymi zapisami w zakresie pozycji Wysokiego Przedstawiciela są: połączenie funkcji przewodniczącego Radzie do Spraw Zagranicznych (wcześniej funkcję tą sprawowała prezydencja rotacyjna) i funkcji wiceprzewodniczącego Komisji Europejskiej i Komisarza do Spraw Zewnętrznych oraz stworzenie ESDZ jako zaplecza operacyjnego i analitycznego dla Wysokiego Przedstawiciela. Istotną zmianą było także przyznanie Wysokiemu Przedstawicielowi inicjatywy prawodawczej w zakresie Wspólnej Polityki Zagranicznej i Bezpieczeństwa (WPZiB), oraz stanowiącej jej część Wspólnej Polityki Bezpieczeństwa i Obrony (WPBiO). Inicjatywa ta przysługiwała przed 2009 r. jedynie państwom członkowskim i Komisji Europejskiej. Pozycja Wysokiego Przedstawiciela została zatem wzmocniona, lecz kompetencje decyzyjne pozostały w rękach państw członkowskich, a konkretnie w rękach dwóch instytucji: Rady Europejskiej i Rady do Spraw Zagranicznych. Traktat zakłada, że Wysoki Przedstawiciel będzie opracowywać, kierować, koordynować i wdrażać WPZiB, podczas gdy sam proces decyzyjny zachowuje swój międzyrządowy charakter. Takie zapisy nakładają na stanowisko Wysokiego Przedstawiciela duże oczekiwania, nie dając mu jednocześnie kompetencji decyzyjnych. W literaturze przedmiotu dominuje przekonanie o pasywnej roli Wysokiego Przedstawiciela. W opinii Żurawskiego vel Grajewskiego, Ashton nie była „decydentem rozstrzygającym o kierunkach WPZiB i reakcjach UE na bieżące wydarzenia, lecz rodzajem „rzecznika prasowego”, który decyzje ogłasza, ale ich sam nie podejmuje” (2012, s. 26). W podobnym duchu ocenia jej kadencję Przybylska-Maszner, wskazując na brak podejmowania inicjatywy przez Ashton i na pełnienie przez nią funkcji koordynacyjnej (2012, s. 48-49). Helwig twierdzi, że Wysoki Przedstawiciel jest zależny od woli państw członkowskich i ich zgody na działanie (Helwig, 2013, s. 251). Sięgając po koncepcje ról, Helwig i Rüger uznali z kolei, że Wysoki Przedstawiciel jest skuteczny w wykonywaniu roli dyplomaty i menedżera, ale nieskuteczny jako współlider i broker (2014). Analiza roli aktywności Wysokiego Przedstawiciela podczas Arabskiej Wiosny potwierdziła, że jest on wykonawcą polityki państw członkowskich i nie podejmuje roli współlidera (Amadio Vicere, Fabbrini, 2017, s. 10). W podobnym duchu, Keukeleire i Delreux argumentowali, że Ashton skupiła się wyłącznie na pracy 
w imieniu państw członkowskich i służbie Radzie, a nie skorzystała z innej możliwej interpretacji swojego mandatu, w której Wysoki Przedstawiciel współkształtuje politykę zagraniczną UE, pośredniczy między państwami członkowskimi i aktywnie przyczynia się do określenia kierunków działań UE (Delreux, Keukeleire, 2016, s. 81). Autorem najbardziej kompleksowego opracowania roli Wysokiego Przedstawiciela jest Helwig, który stosując model pod model pryncypał-agent/mocodawca-wykonawca (principal-agent), wskazał, iż Wysoki Przedstawiciel pełni rolę ograniczonego agenta (constrainted agent) z niewielką autonomią udzieloną mu przez państwa członkowskie pełniące funkcję pryncypała zbiorowego (Helwig, 2014). Jak pokazała kadencja Ashton, państwa członkowskie zdecydowanie chroniły swoją władzę, ale jednocześnie oczekiwały, że Wysoka Przedstawiciel wniesie wartość dodaną (Edwards, 2013, s. 282-283; Helwig, Rüger, 2014, s. 8).

Warto jednakże podkreślić, iż niezależnie od dominującego w literaturze poglądu o pasywnej roli pierwszego postlizbońskiego Wysokiego Przedstawiciela, zapisy traktatowe dają stosunkowo dużą elastyczność w zakresie wypełnienia mandatu przez osobę, pełniącą to stanowisko. Major i Bail wskazywały na „sprzeczność pomiędzy ponadnarodowymi zadaniami przywódczymi dla Wysokiego Przedstawiciela, z jednej strony, a niezmiennie międzyrządową kontrolą zasobów, z drugiej strony" (2011, s. 28). Miszczak zaś nazwał postanowienia dotyczące nowych aktorów mianem „nieprecyzyjnych" (2008, s. 253). Inni badacze komentowali, że decydujące znaczenie dla faktycznej roli Wysokiego Przedstawiciela w procesie decyzyjnym będzie miała praktyka polityczna i sposób, w jaki sprawująca to stanowisko osoba, będzie rozumieć zakres swojego mandatu i wykonywać swoją rolę (Howorth, 2011; Przybylska-Maszner, 2012).

Można się zatem pokusić o twierdzenie, ze spektrum realizacji mandatu przez Wysokiego Przedstawiciela sięga od działań w charakterze ograniczonego agenta kontrolowanego przez pryncypała, który cieszy się niewielkim polem manewru (discretion) i nie proponuje własnych inicjatyw, aż po aktywną rolę polegającą na stosowaniu strategii ukierunkowanych na zwiększenie swojego wpływu i uzyskanie większego pola manewru od swoich pryncypałów. Innymi słowy, Wysoki Przedstawiciel może sprowadzić swoją rolę do koordynacji negocjacji między państwami członkowskimi, lub wykorzystując swoje umiejscowienie instytucjonalne i powierzone traktatem funkcje, może stać się aktorem wnoszącym wartość dodaną. Zgodnie z literą traktatu i faktem pozostawania kompetencji decyzyjnych w rękach państw członkowskich, ich wola w dużej mierze determinuje pole działania Wysokiego Przedstawiciela. Jednakże opierając się na badaniach relacji pryncypał-agent, można stwierdzić, że pole manewru agenta powstaje w dwojaki sposób: mocodawcy mogą przyznać je agentowi w procesie pierwotnego delegowania kompetencji (Ruszkowski, 2012) lub agent może starać się samodzielnie zdobyć lub powiększyć swoje pole manewru - tzw. zdobyte pole manewru (conquered discretion) (Delreux, 2010, s. 3). Zaproponowany poniżej model badawczy skupia się właśnie na drugim rodzaju pola manewru. Na podstawie istniejącej literatury przedmiotu, można bowiem uznać, że tzw. zdobyte pole manewru jest kluczowe do pełnienia funkcji Wysokiego Przedstawiciela w sposób odpowiadający na sformułowane wobec tego stanowiska oczekiwania poprawy spójności i efektywności unijnej polityki zagranicznej i bezpieczeństwa. 


\section{Model badawczy}

Zadaniem niniejszego artykułu jest przedstawienie modelu, który umożliwi analizę roli, jaką Wysoki Przedstawiciel odgrywa w procesie decyzyjnym. Jak wskazano powyżej, kluczowa do oceny roli wydaje się być koncepcja tzw. zdobytego pola manewru Wysokiego Przedstawiciela. Punkt wyjścia do rozważań stanowi pytanie, jakie działania Wysokiego Przedstawiciela mogą prowadzić do zdobywania większego pola manewru i jakie czynniki sprzyjają lub zakłócają ten proces.

\section{Podstawowe kategorie i zmienne}

Podstawowym pojęciem w proponowanym modelu jest kategoria politycznego przedsiębiorcy zapożyczona z polityk publicznych (Cohen, March, Olsen, 1972; Kingdon, 2003). Zgodnie z definicją Kingdona wypracowaną do celów badania polityki wewnętrznej w Stanach Zjednoczonych, przedsiębiorca polityczny opracowuje propozycje i ekspertyzy oraz jest gotowy zaangażować zasoby, takie jak czas, energię, reputację po to, aby forsować swoje pomysły (2003, s. 122-123). Przedsiębiorcy polityczni przedstawiają swoje propozycje, ale także działają jako brokerzy, prowadząc negocjacje między zaangażowanymi stronami i proponując kompromisowe rozwiązania problemów, a w efekcie starając się zainicjować zmianę polityki (policy change) (Mintrom, 1997, s. 738-739). Wysoki Przedstawiciel wydaje się posiadać dwie główne cechy przedsiębiorcy politycznego - 1) zasoby: ESDZ i instrumenty z zakresu działań zewnętrznych UE pozostające do dyspozycji Wysokiego Przedstawiciela jako wiceprzewodniczącego Komisji Europejskiej; 2) możliwość generowania pomysłów i nakłaniania państw członkowskich do działania i w efekcie do zmiany polityki: inicjatywa prawodawcza i obowiązek prowadzenia WPZiB zgodnie z zapisami traktatu z Lizbony (por. Moravcsik, 1999, s. 271-272). Inspiracja do zastosowania koncepcji politycznego przedsiębiorcy do eksploracji roli Wysokiego Przedstawiciela zaczerpnięta została od badaczy, którzy zastosowali to pojęcie do prześledzenia ról różnych aktorów zaangażowanych w proces polityczny na arenie unijnej takich jak Komisja Europejska, Parlament Europejski czy państwa członkowskie (Moravcisk, 1993; Laffan, 1997; Krause, 2003; Ackrill, Kay, 2011; Roth, 2011; Copeland, James, 2014; Palmer, 2015). Pierwsza, która zastosowała koncepcje politycznego przedsiębiorcy do badania unijnej polityki zagranicznej była Federica Bicchi, która analizowała zaangażowanie poszczególnych państw członkowskich traktowanych jako politycznych przedsiębiorców w formułowanie polityki Unii wobec regionu Morza Śródziemnego (2002). Proponowany w niniejszym opracowaniu model korzysta z analizy przeprowadzonej przez Bicci, jednakże skupia się na roli ponadnarodowego aktora, jakim jest Wysoki Przedstawiciel i uwzględnia postlizboński podział kompetencji i relacje międzyinstytucjonalne w zakresie polityki zagranicznej i bezpieczeństwa.

Jak pokazano w poprzedniej części artykułu, proponowany tutaj model zakłada istnienie spektrum, w ramach którego Wysoki Przedstawiciel może kształtować swój mandat. Pojęcie politycznego przedsiębiorcy stanowi uzupełnienie do zaczerpniętej z modelu pryncypał-agent kategorii ograniczonego agenta. Połączenie tych dwóch 
pojęć pozwala na konceptualizację spektrum działania Wysokiego Przedstawiciela, zwiększając tym samym potencjał eksploracyjny modelu. Przyjmuje się założenie, że Wysoki Przedstawiciel może wykonywać swój mandat w zakresie wyznaczonym przez dwie skrajne role: ograniczonego agenta i politycznego przedsiębiorcy. Poniższa tabela przedstawia różnice pomiędzy dwiema rolami w trzech kategoriach: postrzeganie ról, realizacja ról i strategie zaangażowania w proces decyzyjny.

Table 1

\section{Ograniczony agent a przedsiębiorca polityczny}

\begin{tabular}{|c|c|c|}
\hline & $\overline{\text { Ograniczony agent }}$ & 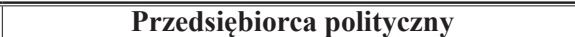 \\
\hline $\begin{array}{l}\text { Postrzeganie } \\
\text { ról }\end{array}$ & $\begin{array}{l}\text { Rola administracyjna; wyplenianie } \\
\text { zadá powierzonych przez pryncy- } \\
\text { pałów; akceptacja dla przekazanego } \\
\text { przez nich pola manewru }\end{array}$ & $\begin{array}{l}\text { Rola polityczna; korzystanie z inicjatywy pra- } \\
\text { wodawczej; dążenie do maksymalnego zwięk- } \\
\text { szenia swojego pola manewru }\end{array}$ \\
\hline Realizacja ról & $\begin{array}{l}\text { Pasywny pośrednik; redukcja kosz- } \\
\text { tów transakcyjnych; skupienie się na } \\
\text { najniższym wspólnym mianowniku }\end{array}$ & $\begin{array}{l}\text { Aktywny moderator; wysuwanie własnych pro- } \\
\text { pozycji; inwestowanie dostępnych zasobów, } \\
\text { aby wplynąć na proces decyzyjny }\end{array}$ \\
\hline $\begin{array}{l}\text { Strategie } \\
\text { zaangażowa- } \\
\text { nia w proces } \\
\text { decyzyjny }\end{array}$ & $\begin{array}{l}\text { Wdrażanie decyzji podjętych przez } \\
\text { Radę; mediacja między państwami } \\
\text { członkowskimi w oparciu o najniższy } \\
\text { wspólny mianownik; ograniczone za- } \\
\text { angażowanie w proces decyzyjny }\end{array}$ & $\begin{array}{l}\text { Identyfikacja nowych problemów politycznych; } \\
\text { przedstawianie własnych propozycji i ich reali- } \\
\text { zacja; zdobywanie wsparcia dla swoich pomy- } \\
\text { słów poprzez zjednywanie podobnie myślących } \\
\text { państw członkowskich; zaangażowanie na } \\
\text { wszystkich etapach procesu decyzyjnego }\end{array}$ \\
\hline
\end{tabular}

Źródło: Opracowanie własne.

Takie postrzeganie możliwości wykonywania swojego mandatu przez Wysokiego Przedstawiciela pozwala na zbadanie, przedstawionego wcześniej, tzw. zdobytego pola manewru.

Model zakłada, że pole manewru jest zmienną zależną, którą można zdefiniować jako „swoboda, jaką dysponuje agent przy wykonywaniu delegowanych zadań” (Delreux, Adriaensen, 2017, s. 6). Pole manewru nie jest tym samym zmienną dychotomiczną i obejmuje cały zakres wykonywania mandatu, jaki mieści się między dwoma skrajnymi rolami: Wysoki Przedstawiciel jako ograniczony agent państw członkowskich lub jako przedsiębiorca polityczny, stosujący różne strategie powiększania swojego pola manewru. Pomiędzy tymi dwoma skrajnościami istnieje wiele możliwości pośrednich, jak wskazuje poniższy wykres.

\section{Wykres 1. Pole manewru Wysokiego Przedstawiciela}

$\mathrm{I}$

Wysoki Przedstawiciel

jako ograniczony agent

(Ograniczone pole manewru)

Źródlo: Opracowanie własne.
Wysoki Przedstawiciel jako przedsiębiorca polityczny (Duże pole manewru)

Model zakłada, ze istnieje mechanizm przyczynowy pomiędzy polem manewru Wysokiego Przedstawiciela a podejmowaną przez niego aktywnością politycznego 
przedsiębiorcy: im bardziej przedsiębiorczy jest Wysoki Przedstawiciel, tym większe pole manewru może zdobyć w relacji z państwami członkowskimi. Prowadzenie aktywności w charakterze politycznego przedsiębiorcy jest zatem postrzegane jako pierwsza zmienna niezależna (ZN1). Aby ją zoperacjonalizować, dokonano syntezy ról i strategii przedsiębiorców politycznych przedstawionych w literaturze (Young, 1991; Checkel, 1993; Moravcsik, 1999; Bicchi, 2002; Mintrom, Norman, 2009). Następnie role te zaadaptowano do mandatu Wysokiego Przedstawiciela i zadań, jakie są mu powierzone na mocy traktatu z Lizbony. W efekcie uzyskano pięć kluczowych ról, w ramach których Wysoki Przedstawiciel może działać jako polityczny przedsiębiorca. Przedstawione są one w poniższej tabeli.

Tabela 2

Wysoki Przedstawiciel jako przedsiębiorca polityczny

\begin{tabular}{|l|l||}
\hline \multicolumn{1}{|c|}{ Funkcje } & \multicolumn{1}{|c|}{ Wykonanie funkcji } \\
\hline Agenda-setter & $\begin{array}{l}\text { Aktywne prowadzenie WPZiB poprzez przedstawianie własnych propozycji; podkre- } \\
\text { ślanie kwestii o szczególnym znaczeniu i unikanie pewnych kontrowersyjnych tematów }\end{array}$ \\
\hline Popularyzator & $\begin{array}{l}\text { Zwrócenie uwagi opinii publicznej na omawiane kwestie i przedstawienie przekonują- } \\
\text { cych dowodów, że istnieje potrzeba działania; prowadzenie wielostronnych konsultacji } \\
\text { w celu omówienia propozycji politycznych; zbieranie poparcia różnych środowisk dla } \\
\text { propozycji politycznych }\end{array}$ \\
\hline Inicjator & $\begin{array}{l}\text { Opracowanie innowacyjnych propozycji politycznych i rozwiązań w celu przezwycię- } \\
\text { żenia przeszkód w negocjacjach }\end{array}$ \\
\hline Broker & $\begin{array}{l}\text { Wypracowywanie kompromisu i zdobywanie poparcia dla pomysłów, za którymi } \\
\text { stoi większość; budowanie koalicji państw członkowskich o podobnych poglądach; } \\
\text { uwzględnianie preferencji państw członkowskich w swoich własnych propozycjach } \\
\text { politycznych }\end{array}$ \\
\hline Realizator & $\begin{array}{l}\text { Osobiste zaangażowanie we wdrażanie decyzji przyjętych przez organy międzyrzą- } \\
\text { dowe }\end{array}$ \\
\hline
\end{tabular}

Źródło: Opracowanie własne na podstawie (Young, 1991; Checkel, 1993; Moravcsik, 1999; Bicchi, 2002; Mintrom, Norman, 2009).

Wykonywane przez Wysokiego Przedstawiciela funkcje są różne na różnych etapach procesu decyzyjnego: przy identyfikacji i sformułowaniu problemu będzie on działał bardziej jako agenda-setter, popularyzator i inicjator, przy samym podejmowaniu decyzji ważniejsza będzie funkcja brokera, zaś implementacja decyzji będzie uwypuklać funkcję realizatora. Z tego względu śladów na aktywność Wysokiego Przedstawiciela w roli politycznego przedsiębiorcy, należy poszukiwać podczas całego procesu politycznego.

\section{Hipotezy}

Tak dobrane zmienne, dopuszczają sformułowanie sześciu hipotez badawczych. Zasadnicza hipoteza, jaką przedstawiony model może zweryfikować, brzmi: H1. Im większa aktywność Wysokiego Przedstawiciela w charakterze politycznego przedsiębiorcy, tym większe pole manewru uzyskuje $w$ relacji z państwami członkowskimi. 
Ponadto, model zakłada istnienie także innych zmiennych niezależnych, które wpływają na zdobyte pole manewru. Analiza literatury poświęconej Wysokiemu Przedstawicielowi oraz przeprowadzone wywiady pogłębione, pozwalają na zidentyfikowanie czterech kolejnych zmiennych. Pierwszą z nich jest dystrybucja preferencji między państwami członkowskimi (ich zgodność lub rozbieżność opinii wobec danej kwestii politycznej (ZN2). Kolejną jest presja czasu, czyli konieczność reagowania na dziejący się kryzys lub inicjowanie działań niezależnie od wydarzeń zewnętrznych (ZN3). Na pole manewru wpływa też posiadana wiedza na temat danego problemu politycznego i fakt, czy zasoby informacyjne podzielone są równo lub czy istnieje asymetria informacyjna na korzyść jednego z aktorów: państw członkowskich lub Wysokiego Przedstawiciela (ZN4). Wreszcie, ostatnią zmienną są stosowane mechanizmy kontrolne, jakimi dysponuje pryncypał wobec agenta, które mogą być rozbudowane bądź ograniczone (ZN5).

Zależność tych zmiennych w relacji do zmiennej zależnej - zdobytego pola manewru, można przedstawić w postaci następujących hipotez:

H2. Im większa zgodność między państwami członkowskimi wokót danej kwestii, tym większa jest możliwość zdobycia pola manewru przez Wysokiego Przedstawiciela.

H3. Im większa presja czasu i konieczność szybkiego działania, tym trudniej Wysokiemu Przedstawicielowi powiększyć swoje pole manewru.

H4. Im większa jest asymetria zasobów na korzyść Wysokiego Przedstawiciela, tym większa możliwość powiększenia zdobytego pola manewru.

H5: Im bardziej rozbudowane sa mechanizmy kontrolne państw czlonkowskich wobec Wysokiego Przedstawiciela i zostaja one zastosowane, tym trudniej mu powiększać zdobyte pole manewru.

\section{Metody i techniki badawcze}

Wdrożenie powyższego modelu wymaga zastosowania wielostopniowego procesu badawczego opartego na badaniach jakościowych, czyli tzw. małym N (small N-studies). Pierwszym krokiem wydaje się być selekcja odpowiednich studiów przypadku (Seawnght, Gerring, 2008; Gerring, Cojocaru, 2015), gdyż taka metoda pozwoli na przeprowadzenie pogłębionej analizy. Jednocześnie określona selekcja przypadków pozwoli na ewentualne wyeliminowanie zmiennych zakłócających takich jak cechy osobowościowe Wysokiego Przedstawiciela. Dobór studiów przypadku w obrębie kadencji jednej osoby pozwoli na traktowanie cech osobowościowych jako stałych. $\mathrm{Z}$ drugiej zaś strony studia przypadku mogą zostać dobrane zgodnie z logiką zróżnicowania (Seawnght, Gerring, 2008, s. 297), co pozwoli uzyskać bardziej reprezentatywne wyniki pozwalające na generalizację wniosków.

W ramach kolejnego kroku - analizy w obrębie studiów przypadku - przydana wydaje się być technika śledzenia procesu (Checkel, 2005; Hall, 2012; Gałganek, 2018; Ławniczak, 2018). Umożliwia ona bowiem śledzenie mechanizmów przyczynowych i udzielenie odpowiedzi na pytanie „dlaczego” oraz „w jaki sposób” oraz testowanie hipotez dotyczących mechanizmów przyczynowych wyjaśniających dany przypadek. Taka metoda umożliwi analizę aktywności Wysokiego Przedstawiciela jako politycz- 
nego przedsiębiorcy w ramach przedstawionych powyżej funkcji, jakie wykonuje - agenda-settera, popularyzatora, inicjatora, brokera i realizatora. Śledzenie procesu pozwoli także na zbadanie, na ile działanie w charakterze politycznego przedsiębiorcy przyczynia się do zwiększenia pola manewru Wysokiego Przedstawiciela, oraz na ile pozostałe czynniki (ZN2, ZN3, ZN4 i ZN5) wpływają na zdobywane pole manewru.

Konieczna do przeprowadzenia śledzenia procesu będzie analiza dokumentów źródłowych dotyczących danego przypadku oraz istniejącej literatury, prasy i opracowań think tanków. Niezbędne do uzyskania wiedzy i informacji, które pomogłyby weryfikować hipotezy, wydają się być także pogłębione wywiady indywidualne z osobami zaangażowanymi w proces decyzyjny dotyczący danego studium przypadku. Przy doborze osób do wywiadów należy zwrócić uwagę, aby wywodziły się one zarówno z otoczenia Wysokiego Przedstawiciela (ESDZ, Komisja Europejska), jak i z państw członkowskich (zarówno w Brukseli: Stałe Przedstawicielstwa państw członkowskich, jak i w stolicach: Ministerstwa Spraw Zagranicznych, Ministerstwa Obrony i inne urzędy państwowe odpowiedzialne za kształtowanie polityki zagranicznej i bezpieczeństwa). Zróżnicowane źródła informacji dają szansę na konfrontację uzyskanych odpowiedzi.

\section{Podsumowanie}

Powyższy artykuł proponuje model, który może zostać zastosowany do badania roli Wysokiego Przedstawiciela w procesie decyzyjnym w zakresie Wspólnej Polityki Zagranicznej i Bezpieczeństwa. Perspektywa 10 lat, jakie upłynęły od wejścia w życie traktatu, pozwala na przeprowadzenie kompleksowej analizy, która pokazałaby, rzeczywistą wartość dodaną, jaką wniosła pozycja Wysokiego Przedstawiciela. Stanowisko to miało poprawić koordynację unijnej polityki zagranicznej i przyczynić się do zwiększenia jej spójności. Badacze analizujący dynamikę postlizbońskiego procesu decyzyjnego na tym obszarze, wskazywali na fakt pozostawania kompetencji decyzyjnych w rękach państw członkowskich i na sprowadzenie Wysokiego Przedstawiciela do roli ograniczonego agenta. Ta obserwacja stanowiła punkt wyjścia do stworzenia modelu, który ma charakter eksploracyjny. Jego celem jest wyjście poza istniejące w literaturze opracowania i wnioski. Korzystając z kategorii stosowanej w politykach publicznych model bada, na ile Wysoki Przedstawiciel działając w charakterze politycznego przedsiębiorcy, może zwiększyć swoje pole manewru w relacji z państwami członkowskim. Model umożliwia także uwzględnienie innych czynników wpływających na pole manewru Wysokiego Przedstawiciela takich jak dystrybucja zasobów informacyjnych czy mechanizmy kontrolne stosowane przez pryncypałów.

Studiami przypadków, które nadawałyby się do zastosowania do weryfikacji hipotez, przedstawionych w modelu, mogłyby być negocjacje umowy nuklearnej z Iranem, powołanie do życia operacji militarnej Sophia, czy przygotowanie i implementacja Strategii Globalnej Unii Europejskiej. Tak zróżnicowane studia przypadku umożliwiłyby maksymalizację potencjału eksploracyjnego modelu, przy jednoczesnym wyłączeniu czynnika dotyczącego osobowości Wysokiego Przedstawiciela, gdyż obejmowałyby jedynie działania F. Mogherini. Jak wspomniano powyżej, dobór studiów przypadku będzie miał wpływ na możliwość generalizacji wniosków. 


\section{Bibliografia}

Ackrill R.; Kay A. (2011), Multiple streams in EU policy-making: the case of the 2005 sugar reform, ,Journal of European Public Policy”, vol. 18, no. 1, s. 72-89, doi: 10.1080/13501763. 2011.520879.

Amadio Vicere M. G., Fabbrini S. (2017), Assessing the High Representative?s Role in Egypt during the Arab Spring, „The International Spectator”, July, s. 1-19, doi: 10.1080/03932729. 2017.1330021.

Bicchi F. (2002), Actors and Factors in European Foreign Policy-making: insights from the Mediterranean case, EUI Working Paper.

Checkel J. (1993), Ideas, Institutions and the Gorbachev Foreign Policy, „World Politics”, vol. 45, no. 2, s. 271-300.

Checkel J. T. (2005), It's the Process Stupid! Process Tracing in the Study of European and International Politics, „Working Paper”, no. 26, Arena, Oslo.

Chruściel M. (2015), Wspólna Polityka Zagraniczna i Bezpieczeństwa, w: Wybrane polityki publiczne Unii Europejskiej: Stan i perspektywy, red. M. Świstak, J. Tkaczyński, Wydawnictwo Uniwersytetu Jagiellońskiego, Kraków.

Cohen M. D., March J. G., Olsen J. P. (1972), A Garbage can Model of Organizational Choice, „Administrative Science Quarterly", s. 1-25, doi: 10.2307/2392088.

Copeland P., James S. (2014), Policy windows, ambiguity and Commission entrepreneurship: explaining the relaunch of the European Union's economic reform agenda, „Journal of European Public Policy", vol. 21, s. 1-19, doi: 10.1080/13501763.2013.800789.

Delreux T. (2010) Measuring and explaining discretion. The case of the EU as international environmental negotiator, prezentacja konferencyjna, Leuven.

Delreux T., Adriaensen J. (2017), The Principal Agent Model and the European Union, Palgrave Macmillan UK, doi: 10.1007/978-3-319-55137-1.

Delreux T., Keukeleire S. (2016), Informal division of labour in EU foreign policy-making, „Journal of European Public Policy", doi: 10.1080/13501763.2016.1216151.

Eysymontt M. (2019), Pozycja instytucjonalna urzędu Wysokiego Przedstawiciela Unii do Spraw Zagranicznych i Polityki Bezpieczeństwa. Od koncepcji, przez narodziny, po nieustanna ewolucje, Wydawnictwo CH. Beck, Warszawa.

Gałganek A. (2018), Metoda śledzenia procesu i mechanizmy przyczynowe w badaniu stosunków międzynarodowych, „Przegląd Politologiczny”, vol. 2, s. 7-30, doi: 10.14746/pp.2018.23.2.1.

Gerring J., Cojocaru L. (2015), Case-selection: A Diversity of Methods and Criteria, Online paper, Boston.

Grzeszczak R. (2013), Globalna rola Europy oraz Wspólna Polityka Zagraniczna i Bezpieczeństwa - od stów do rzeczywistości, Warszawa.

Hall P. (2013), Tracing the Progress of Process Tracing, „European Political Science”, vol. 12, s. 20-30, doi: 10.1057/eps.2012.6.

Helwig N. (2013), EU Foreign Policy and the High Representative's Capability-Expectations Gap: A question of Political Will', „European Foreign Affairs Review”, vol. 18, no. 2, s. 235-254.

Helwig N. (2014), The High Representative of the Union The constrained agent of Europe's foreign policy, Dissertation zur Erlangung des Doktorgrades, Cologne.

Helwig N., Rüger C. (2014), In Search of a Role for the High Representative: The Legacy of Catherine Ashton, „The International Spectator”, vol. 49, no. 4, s. 1-17, doi: 10.1080/ 03932729.2014.956423.

Kingdon J. W. (2003), Agendas, Alternatives and Public Policies, Longman, New York.

Krause A. (2003), The European Union's Africa Policy: The Commission as Policy Entrepreneur in the CFSP, „European Foreign Affairs Review”, vol. 8, s. 221-237. 
Laffan B. (1997), From policy entrepreneur to policy manager: the challenge facing the European Commission, „Journal of European Public Policy”, vol. 4, no. 3, s. 422-438, doi: 10.1080/13501769780000081.

Ławniczak K. (2018), Śledzenie procesu w badaniach politologicznych. Warianty i potencjat zastosowania, „Przegląd Politologiczny”, vol. 1, s. 49-61. doi: 10.14746/pp.2018.23.1.3.

Mintrom M. (1997), Policy Entrepreneurs and the Diffusion of Innovation, „American Journal of Political Science", vol. 41, no. 3, s. 738-770, doi: 10.2307/2111674.

Mintrom M.; Norman P. (2009), Policy Entrepreneurship and Policy Change, „Policy Studies Journal", vol. 37, no. 4, s. 649-667, doi: 10.1111/j.1541-0072.2009.00329.x.

Miszczak K. (2008), Reforma Wspólnej Polityki Zagranicznej i Bezpieczeństwa, w: Traktat z Lizbony. Gtówne reformy ustrojowe Unii Europejskiej, red. J. Barcz, Warszawa, s. 236-253.

Moravcisk A. (1993), Preferences and Power in the European Community: A Liberal Intergovernmentalist Approach, „Journal of Common Market Studies”, vol. 31, no. 4, s. 473-524.

Moravcsik A. (1999), A New Statecraft? Supranational Entrepreneurs and International Cooperation, „International Organization”, vol. 53, no. 2, s. 267-306, doi: 10.1162/002081899550887.

Palmer J. R. (2015), How do policy entrepreneurs influence policy change? Framing and boundary work in EU transport biofuels policy, „Environmental Politics”, vol. 24, no. 2, s. 270-287, doi: 10.1080/09644016.2015.976465.

Przybylska-Maszner B. (2012), Spory kompetencyjne wokót urzędu Wysokiego Przedstawiciela Unii Europejskiej do Spraw Zagranicznych i Polityki Bezpieczeństwa, „Studia Europejskie”, vol. 2, s. 33-56.

Rada Europejska (2013), European Council meeting. Conclusions, Bruksela.

Rada Europejska (2015a), European Council meeting. Conclusions (17 i 18 grudnia 2015). Bruksela.

Rada Europejska (2015b), European Council meeting. Conclusions (25 i 26 czerwca 2015).

Rada Europejska (2017), European Council meeting. Conclusions (19 października 2017), Bruksela. Rada Europejska (2018), European Council meeting. Conclusions (13-14 grudnia 2018). Bruksela.

Rewizorski M., Przybylska-Maszner B. (2013), System instytucjonalny Unii Europejskiej po traktacie z Lizbony. Aspekty polityczne i prawne, Difin.

Roth M. (2011), Poland as a Policy Entrepreneur in European External Energy Policy: Towards Greater Energy Solidarity vis-à-vis Russia?, „Geopolitics”, vol. 16, no. 3, s. 600-625, doi: 10.1080/14650045.2011.520865.

Ruszkowski J. (2012), Pierwotne i wtórne delegowanie kompetencji w wielopoziomowym systemie zarzadzania Unii Europejskiej, „Rocznik Integracji Europejskiej”, vol. 6, s. 45-62.

Seawnght J.; Gerring J. (2008), Case selection techniques in case study research: A menu of qualitative and quantitative options, „Political Research Quarterly”, vol. 61, no. 2, s. 294-308, doi: $10.1177 / 1065912907313077$.

Starzyk-Sulejewska J. (2013), Wspólna Polityka Zagraniczna i Bezpieczeństwa UE a polityka zagraniczna państw czlonkowskich Unii, w: Poziomy analizy stosunków międzynarodowych, red. E. Haliżak, M. Pietraś, PWN, Warszawa, s. 459-482.

Sus M. (2014), The High Representative and the European External Action Service: Towards Institutional Coherence in the Eastern Partnership, w: New Approaches to EU Foreign Policy, red. I. P. Karolewski, M. Wilga, Routledge, s. 56-89.

Tereszkiewicz F. (2013), Proces instytucjonalizacji Wspólnej Polityki Zagranicznej i Bezpieczeństwa Unii Europejskiej, Europejskie Centrum Edukacyjne, Toruń.

Węc J. J. (2011), Reforma Wspólnej Polityki Zagranicznej i Bezpieczeństwa Unii Europejskiej w traktacie lizbońskim, „Politeja”, vol. 15, s. 193-210.

Węc J. J. (2015) Dynamika wspólnej polityki bezpieczeństwa i obrony po wejściu w życie traktatu lizbońskiego, w: Bezpieczeństwo międzynarodowe Polska - Europa - Świat. Księga Jubileuszowa dedykowana Profesorowi Ryszardowi Ziębie z okazji czterdziestolecia pracy naukowej, red. J. Zajac, M. Kaczmarski, A. Włodkowska-Bagan, Warszawa, s. 428-440. 
Young O. R. (1991), Political leadership and regime formation: on the development of institutions in international society, „International Organization”, vol. 45, no. 3, s. 281, doi: 10.1017/ S0020818300033117.

Zięba R. (2003), Unia Europejska jako aktor stosunków międzynarodowych, Wydawnictwo Naukowe Scholar.

Zięba R. (2007), Wspólna Polityka Zagraniczna i Bezpieczeństwa Unii Europejskiej, Wydawnictwa Akademickie i Profesjonalne, Warszawa.

Zięba R. (2018), Stagnacja polityki bezpieczeństwa i obrony jako przejaw kryzysu Unii Europejskiej, w: Kryzysy w Unii Europejskiej w drugiej dekadzie XXI wieku Uwarunkowania-przebieg - implikacje, red. T. Kubin, M. Stolarczyk, Wydawnictwo Uniwersytetu Śląskiego, Katowice, s. 229-348.

Żurawski vel Grajewski P. (2012), Wptyw kryzysu w strefie euro na Wspólna Politykę Zagraniczna i Bezpieczeństwa oraz Wspólna Politykę Bezpieczeństwa i Obrony Unii Europejskiej, „Analizy Natolińskie", vol. 5, nr 57, Centrum Europejskie, Natolin.

\section{Streszczenie}

Artykuł przedstawia model badawczy, który może być zastosowany do analizy roli Wysokiego Przedstawiciela Unii do Spraw Zagranicznych i Polityki Bezpieczeństwa (Wysoki Przedstawiciel) w procesie decyzyjnym. Punktem wyjścia do modelu jest dominujący pogląd odzwierciedlony w literaturze, według którego Wysoki Przedstawiciel jest wyłącznie ograniczonym agentem (constrained agent) państw członkowskich pełniących rolę zbiorowego pryncypała (collective principal). Kluczowym ograniczeniem roli Wysokiego Przedstawiciela wydaje się być pozostawiona w rękach państw członkowskich kompetencja decyzyjna. Proponowany model wprowadza kategorię politycznego przedsiębiorcy i bada, na ile poprzez działanie w charakterze takiego przedsiębiorcy Wysoki Przedstawiciel może zwiększyć swoje pole manewru w relacjach ze zbiorowym zleceniodawcą.

Słowa kluczowe: Wysoki Przedstawiciel, model agenta-mocodawcy, traktat z Lizbony, polityczny przedsiębiorca

\section{High Representative of the European Union for Foreign Affairs and Security Policy as a policy entrepreneur - Proposal for a research approach}

\section{Summary}

The paper proposes a research approach for the examination of the involvement of the High Representative of the Union for Foreign Affairs and Security Issues (High Representative) in the policy-making process. The point of departure is constituted by the predominant view reflected in the literature of the High Representative being solely a constrained agent of the national capitals as a collective principal. A key limitation of the role of the High Representative seems to be that the decision-making power remain in the hands of the Member States. The proposed model introduces the category of a policy entrepreneur and shall examine to what extent, by acting as such, the High Representative can manage to enhance her discretion in relations to the collective principal.

Key words: High Representative, Principal-Agent Approach, Lisbon Treaty, policy entrepreneur 